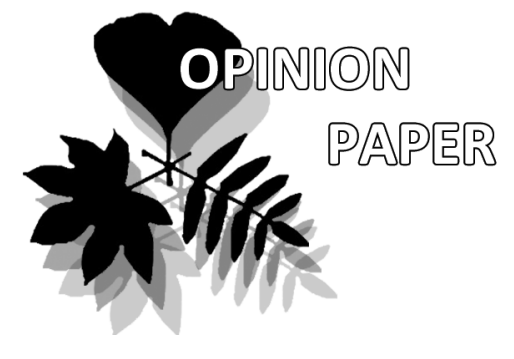

Valentin A. Krassilov

Institute of Evolution, University of Haifa, Mount Carmel, Haifa 3498838, Israel

Manuscript received: 20.04.2015 Review completed: 29.04.2015 Accepted for publication: 29.04 .2015 Published online: 30.04.2015

Note: Current paper is prepared from the texts of Professor Valentin Krassilov (1937-2015)

and presented by Dr Sophia Barinova, Institute of Evolution, University of Haifa, Israel, in his memory

\section{Epistemological approaches to the Systemic Evolution Theory (SET)}

\author{
Valentin A. Krassilov
}

\begin{abstract}
A B S T R A C T
Philosophical approaches to the formation of a new view of the theory of evolution are presented. It expresses the main criticisms to the modern evolutionary paradigm. The basic provisions of The Systemic Theory of Evolution (SET) are formed. They based on the general system theory as thermodynamic principles providing the theoretical framework for investigating particular evolutionary problems like the origin of life and death, progress of life, coherence, adaptation, inheritance, speciation, and cognitive development. In SET, evolution proceeds through ontogenetic renovation of free energy potentials that determine further evolution. Both organismic development and ecological succession are servomechanisms generating the orthogenetic variation systems at the base of speciation, evolutionary grades and syngenesis. The same principles govern cognitive evolution, in which physical reality, inner world and metaphysics are bound by creative interaction.
\end{abstract}

K e y w o r d s : evolution, Darwinism, evo-devo, progress of life, coherence, speciation, cognitive development

\section{P E 3 Ю M E}

Красимов В.А. Эпистемологические подходы к системной теории эвомюции (СЭТ). Представлены философские подходы к формированию нового взгляда на теорию эволюции. Высказаны основные критические замечания к современной эволюционной парадигме. Сформированы основные положения Системной Теории Эволюции. Они основаны на общей теории систем - термодинамических принципов, обеспечивающих теоретическую основу Аля исследования конкретных эволюционных проблем, таких как происхожАение жизни и смерти, прогресса жизни, когерентности, аАаптации, наследования, видообразования и когнитивного развития. Поступательное Авижение в процессе эволюции основано на онтогенетическом обновлении свободных энергетических потенциалов генома, определяющих Аальнейшее развитие. Развитие организмов и экологическая сукцессия явАяются основными сервомеханизмами, порожАающими поступательное развитие системы на базе видообразования, эволюции видов и сингенезиса. Те же принципы регулируют когнитивную эволюцию, в которой физическая реальность, внутренний мир и метафизика, связаны творческим взаимодействием.

К $\boldsymbol{\Lambda}$ ю че в ы е с $\mathbf{\Lambda} о$ в а : эволюция, Аарвинизм, evo-devo, прогресс жизни, когерентность,видообразование, когнитивное развитие
Current reductionist evolution theory is inadequate to the immense complexity of multilevel process it describes and cannot be improved by ad hoc revamps. Its implications are degrading both to science and humanities. The only viable alternative is systemic approach based on general principles of seen as comprehensive philosophic synthesis of natural science, consequential for existential theories, epistemology, cognitive modes, social practices, and human perspectives at large. People still believe that the only scientific alternative to evolution by means of natural selection is mutational chaos and random drift, because spontaneous directedness, progress of life, and free will are long disproved. But they are not, while meaninglessness is an artifact of epistemological reduction (Krassilov 2014 a).
It is commonly believed that reduction is needed for analytical purposes, such as contriving experimental design. Yet experimental design has to be adequate to what is purported to be studied with it. Simple experimental design is the valid testing ground for a simplistic idea, but not for an idea of considerable complexity. Therefore, let us contrive an experimental design of respective complexity or let us reduce the idea to make it testable? Modern science is after the latter. The unsolved problems of evolution, and this are the major problems of evolution, are skillfully explained away as non-existent or insignificant (Krassilov 1986).

You ask about progress of life? Well, can you define what progress of life is minding that bacteria are so marvelously adaptive? If not, what are you talking about? You marvel 
at morphological sophistication of higher animals? Well, you need not. They are just spandrels between the carrying constructions of life rather than constructions themselves. Our theory is about winners, not spandrels. You point to observations not accounted for by our theory? Very well, they are curiosities that a serious theory is not obliged to account for; of course there are more bizarre things on earth than our science cares to dream of.

In a sense, all biology is about curiosities, therefore ambiguous, uninteresting and unneeded. Charles Darwin himself started the process of liberating theory from factual evidence by attacking paleontology as a source of "imperfect" (false) data. The other organismic disciplines followed the suit. August Weismann's dualism has made germ plasma, rather than organism, the essence of life, which is an excuse for substituting life science by chemistry, mathematics, robotics, and whatever non-living.

The term Darwinism was proposed, almost simultaneously and perhaps independently, by Huxley, Wallace and Haeckel, referring to the origin of species by natural selection, a major mechanism of evolutionary change. This is commonly considered to be one of the greatest achievements in the history of science and crucial for our modern worldview. Darwin therefore is glorified as a genius who not only revealed and explained evolution, but also, and foremost, forwarded human intellectual development to the heights of its present day glorious perspective. Unlike the pre-Darwinian natural philosophy, Darwin's theory is believed to be fed by solid empirical evidence and so robust that it smoothly incorporated all later achievements without affecting basic postulates.

The modern (Neo-Darwinian) evolutionary synthesis is an extended version of it. Empedocles, the founder of evolution theory, has ascribed determinism of it to the prevalence of Love (coherence, cooperation) over Strife (struggle, selection). The current theory says that evolution is driven by random variation, with a few variants randomly fitting the circumstances that randomly occur. After billions of years of random adaptation to random circumstances the process turned out utterly absurd, and the appearance of humans with their sinful sex organs and deceptive mind is evidence of it. Thus, in the final countdown, evolution of the theory is fairly predictable: you reap what you sowed.

Scientific opposition to Darwinism was loudly vociferous during Darwin's lifetime and until 1930s, but rapidly diminished and eventually faded out, which is taken to be overwhelming evidence of Darwin's righteousness. Darwinism is sometimes considered to be a rival theory of divine creation and therefore false from religious standpoint, but the arguments are largely misplaced. Faith does not spring from scientific evidence, and God or Darwin is a false alternative. A theory of evolution can be evaluated from a theological exegesis stand point, rather than through bringing it to direct collation or confrontation with the Bible, Torah, Koran or Dhammapada. In addition, creationists have to decide on what to oppose: evolution or Darwin. The identification of evolution with Darwin's theory of it only makes the confusion inextricable.

In respect to the criticism the theory evokes, the often raised arguments are that although the existing theory is admittedly imperfect, there is no viable alternative in view; and because truth is relative, what appears true today would turn wrong tomorrow, and etc. Convincing or not, these arguments fail in respect to the theory of evolution (speciation) by means of natural selection. It has appeared as alternative to classical evolutionism, V century BC-XIX century AD, actually as a vulgate of it, reducing the whole system of ideas under the concept of evolutionary progress to a minor Strife factor of Empedoclean theory. By denying progress of life, Darwin's theory denies evolution of any meaning at all: about 3.7 billion years of jogging in place. Not a theory of evolution at all, but a display of a highly conservative and static worldview.

Declaring survival the only goal of survival and the fittest being those who survives is a too pedestrian standpoint to be illuminating. Rather it unties the baser instincts and desires once thought shameful, now legitimized as natural. Whether such 'theory' is better than nothing is not selfevident. Relativity of truth has nothing to do with the case, because there is no truth in it. Making Darwin the single-handed creator of evolution theory is not a fear tribute to great man, but a deliberate falsification of history in order to establish Darwin cult in order to scare off opposition. As for empiric evidence from which the theory purportedly sprung, observing selection is not the same as observing speciation by means of selection, hitherto never observed. Moreover, Darwin had no evidence of natural selection even, relying on artificial selection, which is not a mechanism of evolution at all.

On the intellectual front, because Darwin's reductionist approach is pragmatically successful, it encourages further reduction (Krassilov 2014 b). A total war against meanings is declared, and not only biology, but everything is going to be reduced to indeterminism, randomness, 'neutrality' and, in the final count down, absurdity.

More objections will be considered through the book, but the abovementioned seem critical for this lingering paradigm persistence and the presently uncertain perspectives of its replacement, questioning the unbound admiration it evokes. The theory far surpassed the limits of lossless reduction by considering only one regulation mode (selection) for a complex system of multiple regulation levels. This is not the matter of shortcomings to be amended. Classical theory had evolution to be an open process with many entries for external stimuli, whereas Darwin made it closed, with no entries, but an exit for internal energy, thus untenable.

How happened that evolutionists endorsed a theory that denies evolution any meaning thus leaving their field of research without subject? I am addressing this question to myself in the first place. In 1977 I published a book "Evolution and Biostratigraphy", mildly critical of selectionist paradigm on various points, but conformist in principle. My professional field was then biostratigraphy, an economically important field of geological research that, with advent of the Neo-Darwinian paradigm, lost any theoretical foundation, because Lyell, Darwin, Huxley and followers denied time correlation by fossils, considering paleontological sequences to be homotaxial, but scarcely synchronous. This led me to revise the Lyell's - Darwin's 
gradualism, a groundless belief pending in a dead zone between science and theology.

I have sought compromise in distinguishing the coherent and non-coherent evolution processes (Krassilov 1969 and subsequent work), driven by cooperative interaction and nonselective elimination, respectively. The non-coherent part of the story was thought to be essentially Darwinian in respect to high proliferation rates (fitness) compensating for mass mortality, but later understood as maladaptive in respect to the higher order systems and biosphere as a whole; proliferation is not a mark of fitness, but on the contrary. Because biosphere is superimposed on the external geospheres, biological evolution is susceptible to geological regulation in the form of geobiological crises - stabilization cycles. The turning points are natural divides over the sequence of paleobiospheres, recognizable through the time-specific geophysical, geochemical and biological signatures that constitute a set of biostratigraphic markers (Krassilov 1974).

The mechanisms of geological perturbations and their interaction with the living component of biosphere are poorly understood. Since 1985, I am working on the rotation model of global change that links tectonic processes to sea level fluctuations, volcanic activities, climate change, and ecosystem turnovers (Krassilov 1975, 1989, 2003, 2013; Krassilov \& Barinova 2013; Krassilov et al. 2014). The model of geobiological evolution (Krasilov 2003) relates the coherent change of critical state parameters, biomass to deadmass production rates scaling to biological diversity to the maintenance work at the ecosystem and population levels in response to concerted geological - climatic pressure mounted by rotation forcing (Krassilov 2013).

The somewhat mechanistic Cuvierian catastrophism, making no distinction between mass mortality and extinction, is replaced therein by alternation of coherent vs. non-coherent evolution modes (Krassilov, 1969 and subsequent work), explaining the periodicity of ecosystem evolution and subordinate levels of biological complexity. In this scheme, population densities are regulated through the ecosystem mechanisms of bottom up attenuation of biomass over the trophic cascades, environmental grain sensitivity, and the Leto/Niobe reproductive strategies (Krassilov 2003 and elsewhere). Blunt denial of progress makes evolution meaningless, and the dogmatic denial of the life experience inheritance makes life absurd, therefore betraying misunderstanding of the processes.

I proposed a genome renovation mechanism through correlation of transcription and replication rates scaling to metabolic gene activity (Krassilov 1980), suggesting that epigenesis is not a side issue but the mainstream of genome evolution. When collate with morphology, the wealth of data obtained by the recent evo-devo studies reveal the meaning of the multitude of transcription regulators as a genetic memory mechanism linking gene expression to hormone signaling through which the genome processing is linked to metabolic demands imposed by the maintenance work in response to environmental pressure (Krassilov et al. 2013).

History enters development as heredity and is projected into future by means of epigenetic renovation of developmental program. This principle determines the relationships between ontogeny and phylogeny at the genomic, organismic, and ecosystem levels, converting complexity of developmental programs into directedness and determinism of evolutionary developments.

The Systemic Evolution Theory (SET) is based on the general system theory - thermodynamic principles providing the theoretical framework for investigating particular evolutionary problems like the origin of life and death, progress of life, coherence, adaptation, inheritance, speciation, and cognitive development (Krassilov 2014 c).

In SET, evolution proceeds through ontogenetic renovation of free energy potentials that determine further evolution. Both organismic development and ecological succession are servomechanisms generating the orthogenetic variation systems at the base of speciation, evolutionary grades and syngenesis, with angiosperm origin as an example (Krassilov 1975, 1989, 1997). The same principles govern cognitive evolution, in which physical reality, inner world and metaphysics are bound by creative interaction (Krassilov 1995).

I consider this work as not an accomplished theory of evolution, but a step toward such; not so problem solving as arising at the level of intellectual complexity adequate to the problems to be solved (rather than solved away by means of epistemological reduction).

A considerable volume of information involved is only sustainable on condition of complexity of information processing. The SET is fairly open, with more entries for energy and material than the classical evolution theory ever furnished, not speaking of the dogmatic STE. I would not close it by means of catchwords like extinction of the fittest or non-evolution by means of natural selection, or even progressive development through transmission of life experience on line, although these statements agree with my general conclusions. In respect to immense complexity of the processes and structures under consideration, the SET further development must be elaboration rather than simplification, requiring most action rather than the least.

These theses are further developed through the book (Krassilov 2014 c). No progress is achievable with a theory that denies progress in principle. However, the richness of productive ideas advanced and silenced during the rule of selection paradigm, but still retrievable, warrants redemption of evolution theory and human perspectives with it.

\section{LITERAT URE CITED}

Krassilov, V.A. 1969. Phylogeny and systematics. In: Problems in Phylogeny and Systematics, (M.N. Gramm \& V.A. Krassilov, eds.), pp. 12-30, Dal'nevostochnyi Nauchnyi Tsentr Rossiiskoi akademii nauk, Vladivostok (in Russian with English abstract). [Красилов В.А. 1969. Филогения и систематика // Проб̆емы филогении и систематики / под реА. М.Н. Грамма и В.А. Красилова. ВАадивосток: АВНЦ РАН. С. 12-30].

Krassilov, V.A. 1974. Casual biostratigraphy. Lethaia 7:173-179.

Krassilov, V.A. 1975. Paleoecology of terrestrial plants. Basic Principles and techniques. Wiley (Israeli Program of Scientific Translations, Jerusalem), N.Y.-Toronto, 283 pp.

Krassilov, V.A. 1977. Evolution and Biostratigraphy. Nauka, Moscow, 254 pp. (in Russian). [Красилов В.А. Эволюция и биостратиграфия. Москва: Наука. 254 с.]. 
Krassilov, V.A. 1980. Directional evolution: a new hypothesis. Evolutionary Theory 4:203-220.

Krassilov, V.A. 1986. Unsolved Problems of Evolutionary Theory. Dal'nauka, Vladivostok, 147 pp. (in Russian). [Красимов В.А. 1986. Нерешенные проблемы теории эволюции. ВАаАивосток: Аальнаука. 147 с.]

Krassilov, V.A. 1989. Origin and early evolution of angiosperms. Nauka, Moscow, 263 pp. (in Russian). ККрасилов B.A. 1989. Происхождение и раннее развитие цветковых растений. Москва: Наука. 263 с.].

Krassilov, V.A. 1995. Ecosystem and Egosystem Evolution. Pensoft, Sofia, $172 \mathrm{pp}$.

Krassilov, V.A. 1997. Angiosperm Origins: Morphological and Ecological Aspects. Pensoft, Sophia, 270 pp.

Krassilov, V.A. 2003. Terrestrial Palaeoecology and Global Change. Pensoft, Sophia, 464 pp.
Krassilov, V.A. 2014 a. Essay on evolution and humanities. International Journal of Humanity and Social Science 4, 11(1):76-85.

Krassilov, V. 2014 b. On Pragmatism, Life, and Evolution. International Journal of Philosophy 2(6):72-79.

Krassilov, V.A. 2014 c. Evolution: System Theory. Pensoft, Sofia, Moscow, $414 \mathrm{pp}$.

Krassilov, V. \& S. Barinova 2013. Sea level - geomagnetic polarity correlation as consequence of rotation geodynamics. Earth Science 2(1):1-8.

Krassilov, V.A., A. Berner \& S. Barinova 2013. Morphology as clue to developmental regulation: stomata. Plant 1(3): 30-44.

Krassilov, V., S. Barinova \& S. Rybnikov 2014. Rotation forcing of tectonics and climate. Earth Science 3(3):68-75. 